\title{
Oestrous cycle-dependent equine uterine immune response to induced infectious endometritis
}

\author{
Christina D. Marth ${ }^{1,2^{*}}$, Simon M. Firestone ${ }^{1}$, Lisa Y. Glenton ${ }^{1,2}$, Glenn F. Browning ${ }^{1}$, Neil D. Young ${ }^{3}$ \\ and Natali Krekeler ${ }^{1,2}$
}

\begin{abstract}
Infectious endometritis is a major cause of reduced pregnancy rates in horses. The objectives of this study were to establish a timeline of the innate immune response in the uterus of healthy horses and to investigate the oestrous cycle effect on this. Endometrial biopsies were collected from five horses before and at 3, 12, 24, 48 and $72 \mathrm{~h}$ after inoculation of Escherichia coli, once in oestrus and once in dioestrus. They were analysed by quantitative real-time PCR, microbiology and histology. Neutrophil numbers increased from very low levels in the absence of inflammation to severe neutrophilia $3 \mathrm{~h}$ after inoculation. The concentrations of mRNAs for Toll-like receptor (TLR)2, TLR4, NOD-like receptor NLRC5, tissue inhibitor of metallopeptidases 1 (TIMP1) and chemokines CCL2, CXCL9, CXCL10 and CXCL11 were all increased $3 \mathrm{~h}$ after inoculation of $E$. coli compared to levels detected prior to inoculation. Chemokine mRNA levels remained elevated for $48 \mathrm{~h}$. Concentrations of mRNAs for the antimicrobial peptides equine $\beta$-defensin 1 (EBD1), lysozyme, secretory leukoprotease inhibitor (SLPI), lipocalin 2 (LCN2), lactoferrin and uteroferrin were increased between 3 and $12 \mathrm{~h}$ post inoculation. The gene for secreted phospholipase $A_{2}\left(S P L A_{2}\right)$ was expressed constitutively. P19 uterocalin mRNA levels were higher in dioestrus than in oestrus over the first $24 \mathrm{~h}$ of inflammation. Neutrophils and many innate immune genes responded rapidly to the introduction of $E$. coli into the uterus, while the oestrous cycle stage had only a relatively minor effect on the response to $E$. coli. This study has delineated a useful model of innate immunity in infectious endometritis of healthy animals.
\end{abstract}

\section{Introduction}

Approximately $15 \%$ of all Thoroughbred broodmares show signs of persistent mating-induced endometritis (PMIE), a local inflammation of the superficial layers of the uterus after breeding [1]. This has a significant impact on the horse breeding industry because of its effect on pregnancy rates in affected mares [2].

Both natural breeding and artificial insemination induce a transient physiological endometritis to clear the uterus of introduced spermatozoa, seminal plasma, bacteria and cell debris $[3,4]$. This contamination induces an inflammatory response with neutrophilia and increased

\footnotetext{
*Correspondence: christina.marth@unimelb.edu.au

${ }^{2}$ Translational Research and Animal Clinical Trial Study Group, Faculty of Veterinary and Agricultural Sciences, The University of Melbourne, Werribee, VIC, Australia

Full list of author information is available at the end of the article
}

mRNA levels of several genes associated with the innate immune response $[5,6]$. Similarly, the introduction of bacteria into the uterine environment has also been shown to cause neutrophilia and increased mRNA levels of several "innate immune" genes [7].

Bacterial uterine infections are found in $25-60 \%$ of barren mares $[8,9]$, with the two most commonly isolated bacteria, Escherichia coli (E. coli) and Streptococcus equi subspecies zooepidemicus (S. equi ss zooepidemicus) both regarded as opportunistic pathogens [10]. While PMIE is an inflammatory response to semen, mares susceptible and resistant to PMIE have also been shown to react differently to an intrauterine inoculation of bacteria [7]. This knowledge has been used in multiple studies, analysing infectious endometritis to investigate differences between healthy mares and those susceptible to PMIE [11-13]. 
Furthermore, studies have suggested that the efficiency of the uterine immune response is affected by steroid hormones and that the uterus faces different challenges depending on the stage of the oestrous cycle $[14,15]$. A previous next-generation sequencing study found that several pathways related to the immune response were enriched in the oestrus gene expression profiles of cycling mares when compared to their dioestrus profiles, suggesting increased immunological vigilance during oestrus [16]. Inoculation of $E$. coli into the uterus of healthy mares during oestrus [7] results in a much less pronounced inflammation than in dioestrus [17], in which purulent or serohaemorrhagic vaginal discharge, heavy bacterial growth and acute systemic inflammation were detected. A high-throughput sequencing study identified 1500 genes with significant differences when directly comparing samples taken $3 \mathrm{~h}$ after inoculation of $E$. coli in oestrus with those taken at the same time point in the same horses in dioestrus [18]. Overall, these studies suggest that hormone levels affect the immune response in the equine uterus.

As susceptibility to PMIE depends on differences within the first few hours after breeding, the most important factors involved in this immune response are likely to be part of the innate immune response. To gain an indepth understanding of the innate immune cascade in the equine uterus, a next generation sequencing analysis was performed on samples taken from the equine uterus before and $3 \mathrm{~h}$ after inoculation of healthy mares with $E$. coli. It identified a number of immune response genes that were up-regulated after the introduction of $E$. coli, particularly in the pathogen recognition receptor (PRR) family, the chemokine and cytokine families and the antimicrobial peptide group [18].

The presence of bacteria in the body is detected by PRRs such as the Toll-like receptors (TLRs) and nucleotide-binding oligomerisation domain (NOD) receptors (NLRs). TLRs have been detected in the reproductive tracts of several mammals, including horses [19]. TLR4 is the primary receptor responsible for the detection of lipopolysaccharide (LPS), a conserved pathogen-associated molecular pattern (PAMP) of Gram-negative bacteria [20, 21], while TLR2 may have a supporting function in detecting LPS [22]. NLRs are responsible for the intracellular detection of pathogens and can activate proinflammatory cytokines [23].

Another important group of factors that participate in the innate immune response are the chemokines, the main function of which is the regulation of transendothelial leucocyte migration [24]. In addition, an antimicrobial potential has been identified for CXCL9, 10 and 11 $[25,26]$.

The endometrium, like other mucous membranes, also uses antimicrobial peptides in its defence against bacteria. They can destabilise bacterial cell walls, interfere with bacterial enzymes or inhibit bacterial iron acquisition and have been detected in multiple organs in the horse [27]. Several defensins have been shown to disrupt the integrity of the bacterial cell wall by pore formation, while lysozyme uses the hydrolysis of peptidoglycans for a similar effect [28]. Secreted phospholipase $\mathrm{A}_{2}\left(\mathrm{sPLA}_{2}\right)$ plays a comparable antibacterial role [29]. Secretory leukoprotease inhibitor (SLPI), which is homolog to equine neutrophil antimicrobial peptide 2 (eNAP-2) [30], selectively inhibits microbial serine proteases [31, 32]. The binding of elements essential for microbial metabolism, such as iron, achieves bacteriostasis [28]. This mechanism is used by lipocalin 2 (LCN2) [33] and lactoferrin (LFN) [34], which also binds to Lipid A of LPS [35]. Uteroferrin (UFN) is essential in trans-placental transport of iron in pigs and horses [36, 37], although it has not previously been implicated in the equine immune response. Another transport molecule associated with fatty acid transport in early equine pregnancy is P19 uterocalin, the production of which is stimulated by progesterone [38].

Tissue inhibitors of metalloproteinases (TIMPs) regulate matrix metalloproteinases (MMPs), which, in turn, have been shown to influence several components of the immune response, particularly chemokines $[39,40]$. The ratio of MMP9 and TIMP1 has previously been correlated with neutrophil, eosinophil and lymphocyte counts during inflammatory processes in the lung [41].

The previous next-generation sequencing study performed on samples taken before and $3 \mathrm{~h}$ after inoculation of $E$. coli in the equine uterus revealed that several genes were up-regulated in response to the introduced bacteria. These included PRRs, as well as several antimicrobial peptides, chemokines, cytokines and MMPs [18]. The results of this RNA-Seq study were used to select a range of genes for analysis at later time points. Thus, the current study follows up on the previous high-throughput sequencing study by establishing a temporal profile of uterine innate immune responses in healthy horses up to 3 days after inoculation of $E$. coli using quantitative real-time PCR (qPCR). The objectives of this study were to evaluate a set of genes for inflammatory and antimicrobial factors as markers of equine endometritis and to investigate the effect of the oestrous cycle stage on expression of these genes.

\section{Materials and methods}

\section{Selection of experimental animals}

Endometrial biopsies were obtained from five Standardbred mares aged between 3 and 4 years. They were maintained on pasture at the facilities of the Faculty of Veterinary and Agricultural Sciences, The University of 
Melbourne, Australia. Treatments and procedures were approved by the University of Melbourne Animal Ethics Committee (Approval Number: 1112297).

For this study, clinically healthy mares were confirmed to be resistant to PMIE based on histopathological evaluation of the endometrium and by insemination with frozen stallion semen during oestrus. This reliably induces uterine inflammation [42]. There were no clinical signs of persistent inflammatory oedema or intrauterine fluid $24 \mathrm{~h}$ after insemination. A histopathological evaluation by two independent examiners classified samples from all five mares in category I according to Kenney and Doig's classification [43]. The absence of any pre-existing bacterial infection in the uterus was confirmed by conventional bacteriological culture of uterine swabs collected from each mare prior to insemination.

\section{Preparation of $E$. coli inocula}

An E. coli strain (EC_CM1) isolated from the reproductive tract of a mare susceptible to post-breeding endometritis was stored at $-80{ }^{\circ} \mathrm{C}$. To prepare inocula the strain was streaked onto a Mueller-Hinton agar plate and incubated for $24 \mathrm{~h}$ at $37^{\circ} \mathrm{C}$. A single colony was transferred to $2 \mathrm{~mL}$ of Mueller-Hinton broth and the broth incubated overnight at $37^{\circ} \mathrm{C}$. The overnight broth culture was diluted to achieve a final concentration of $10^{5}$ colony forming units (CFU) per inoculum. The inocula were kept on ice for a maximum of $1 \mathrm{~h}$ before use.

\section{Inoculation of $E$. coli and collection of endometrial tissue and swab samples}

Follicle development, intrauterine fluid, development of uterine oedema and cervical and uterine tone were monitored daily by trans-rectal palpation and ultrasonographic examination to determine the stage of the oestrous cycle. Rectal temperature, heart rate and respiratory rate were monitored daily or at each sample collection.

A five tier oedema score system (E0-E4), with E0 representing the absence of any uterine oedema and $\mathrm{E} 4$ representing pathological inflammatory oedema, was used to evaluate uterine oedema indicative of cycle stage and/ or inflammation.

Mares were inoculated with E. coli in two consecutive oestrous cycles in a crossover study design (Figure 1). The three randomly assigned mares in group 1 were inoculated with $E$. coli during oestrus, as indicated by the presence of a dominant follicle $\geq 35 \mathrm{~mm}$ in diameter, uterine oedema and decreased uterine and cervical tone. A sample for uterine culture was collected using a double-guarded swab (Minitube Australia, Ballarat, VIC, Australia), before endometrial tissue samples were obtained by trans-cervical biopsy before $(0 \mathrm{~h})$ and 3,12 ,
24, 48 and $72 \mathrm{~h}$ post inoculation (pi) using an alligator jaw biopsy punch (Jorvet, Loveland, CO, USA). Care was taken to obtain biopsies from different sites at the base of the uterine horns alternating the left and right horn at each time point.

During the following oestrus, the absence of inflammation was established by the lack of pathological oedema, as well as the lack of neutrophilia or detectable bacterial growth. The same mares were then inoculated with the same strain of $E$. coli during dioestrus, as indicated by detection of a functional corpus luteum and the absence of uterine oedema 5 days after ovulation. In addition, serum samples were obtained to evaluate plasma progesterone prior to collection. Endometrial biopsies and swabs were again taken before $(0 \mathrm{~h})$ and $3,12,24,48$ and $72 \mathrm{~h}$ pi.

The two mares assigned to the second group were subjected to the same procedures in reverse order, being initially inoculated during dioestrus and subsequently during oestrus. Samples were taken at the same time points using the same methods as described above (Figure 1).

After collection, all endometrial biopsies were divided into three sections with a sterile scalpel blade. One section was used immediately for microbiological culture. One section was snap-frozen in liquid nitrogen in OCT embedding medium (Tissue-Tek, Olympus Australia Pty. Ltd, Mount Waverly, VIC, Australia) and stored at $-80^{\circ} \mathrm{C}$ until further processing. The final section was placed in RNAlater (Life Technologies Australia, Mulgrave, VIC, Australia) and incubated overnight on a rocking platform at room temperature before being stored at $-80^{\circ} \mathrm{C}$ until further processing.

\section{Preparation of samples for microbiology}

The portion of the biopsy used for microbiological culture and the uterine swab sample were used to inoculate Mueller-Hinton-Agar plates, which were then incubated aerobically at $37^{\circ} \mathrm{C}$ for $24 \mathrm{~h}$ to quantify and identify the bacteria in the uterus. Colony counts were scored as: no growth $(<5$ colony forming units (CFU)); mild growth (5-10 CFU); moderate growth (11-50 CFU); and heavy growth ( $>50 \mathrm{CFU})$, as described previously [44].

Representative colonies from each plate were replated onto MacConkey agar to confirm their identity as E. coli by assessing their capacity to ferment lactose and to produce indole from tryptophan. Results were recorded as $E$. coli or other uterine pathogen/contaminant.

\section{Histopathology}

The OCT embedded sections of the 0, 3, 12 and $24 \mathrm{~h}$ samples were mounted on a cryostat (Leica, North Ryde, Australia) to cut 7-10 $\mu \mathrm{m}$ thick tissue sections, which 


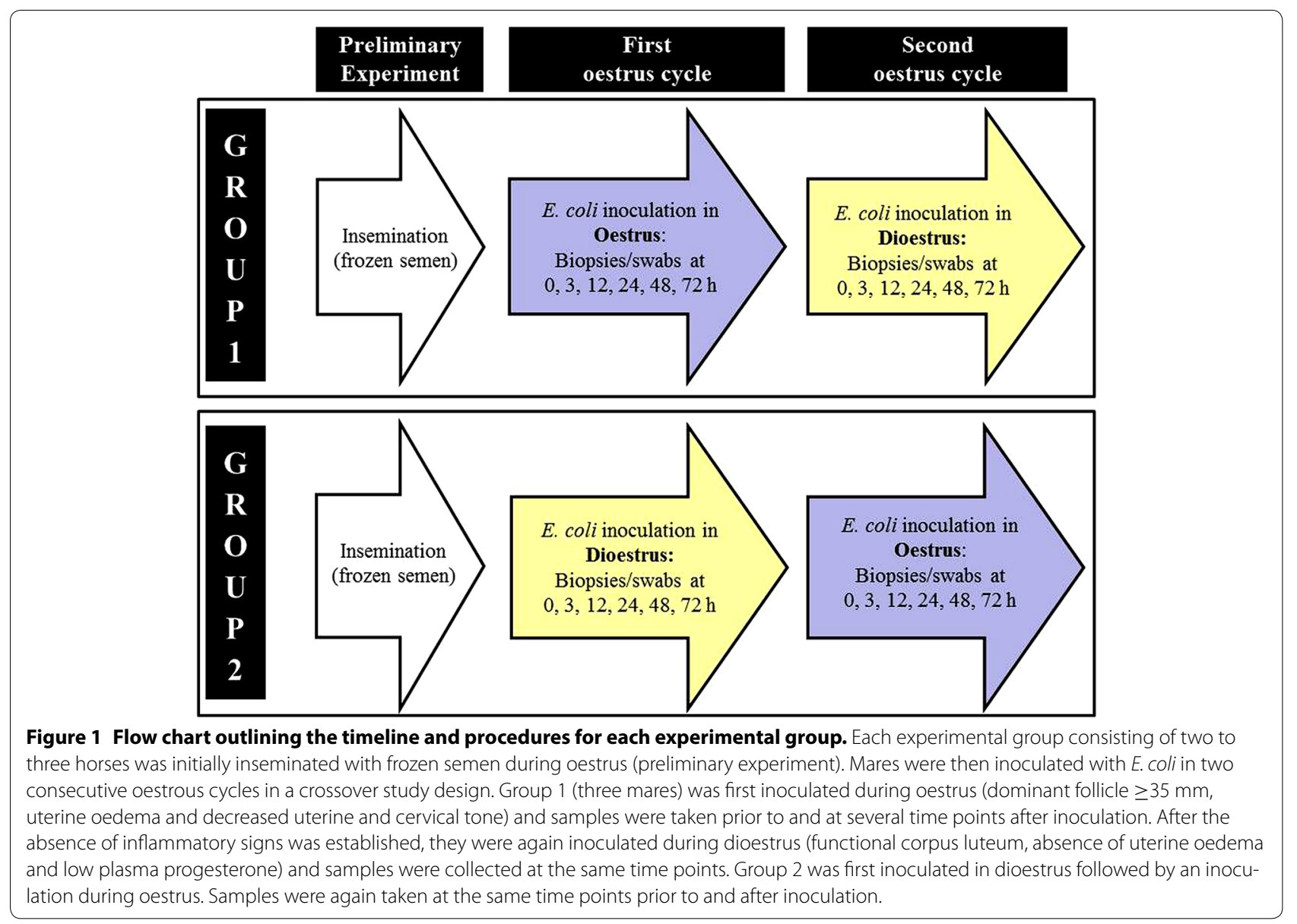

were stained with haematoxylin and eosin (H\&E). Histopathological assessments of the endometrium were made on $0 \mathrm{~h}$ samples according to Kenney and Doig's classification [43].

Classification of the extent of inflammation was based on the total number of neutrophilic leukocytes present in three fields at a magnification of $400 \times$, with the categories assigned being: no neutrophilia $(<10$ neutrophils in total in the three fields), moderate neutrophilia (10-99 neutrophils in total in the three fields), severe neutrophilia (100-149 neutrophils in total in the three fields) and very severe neutrophilia ( $>150$ neutrophils in total in the three fields). In addition, the presence of neutrophils in the epithelial layer and in the endometrial glands was determined for each field and the total number of eosinophil leukocytes was counted.

\section{RNA extraction and CDNA synthesis}

The endometrial biopsy samples placed in RNAlater were homogenised in Trizol (Qiagen, Chadstone, VIC, Australia) using a Polytron homogeniser (IKA Works, Selangor, Malaysia) and the total RNA was purified using the RNeasy Universal Plus Mini Kit (Qiagen) according to the manufacturer's instructions. The total RNA was resuspended in $70 \mu \mathrm{L}$ RNAse-free water and the nucleotide concentration and purity was assessed for each sample by spectrophotometry using a NanoDrop ND-1000 (Thermo Fisher Scientific Australia Pty Ltd, Scoresby, VIC, Australia). All samples had $\mathrm{A}_{260} / \mathrm{A}_{280}$ ratios greater than 1.99 and $\mathrm{A}_{260} / \mathrm{A}_{230}$ ratios greater than 1.82. RNA samples were reverse-transcribed using the iScript cDNA synthesis kit (Bio-Rad, Gladesville, Australia) according to the manufacturer's instructions and the resulting cDNA diluted to a concentration equivalent to $2 \mathrm{ng}$ total original RNA/ $\mu \mathrm{L}$ with RNAse-free water.

\section{Quantitative real-time PCR}

Genes were chosen for further analysis by PCR based on the analysis of next-generation sequencing data published previously [18]. These included the genes for the Toll-like receptors TLR2 and 4, the NOD-like receptor NLRC5, the chemokines CCL2, CXCL9, CXCL10 and CXCL11, as well as the antimicrobial peptides equine $\beta$-defensin 1 (EBD 1), lysozyme, secretory leukoprotease inhibitor 
(SLPI), secreted phospholipase $\mathrm{A}_{2}\left(\mathrm{sPLA}_{2}\right)$, lipocalin 2 (LCN 2), lactoferrin, uteroferrin and the uterocalin precursor (P19). In addition, seven genes with little variation were selected from the sequencing data: $\beta$-actin, glyceraldehyde-3-phosphate dehydrogenase (GAPDH) and the ribosomal proteins (RP) RPL17, RPL27A, RPL30, RPL32 and RPS5.

Primers used to detect the EBD 1 [45] and $\beta$-actin [17] genes were sourced from the literature, while specific primer pairs for all other genes of interest were designed using the NCBI nucleotide blast website [46]. Where possible, primer pairs spanned at least one intron to prevent amplification of contaminating genomic DNA (Table 1). The oligonucleotide sequences are shown in Table 1 and were commercially synthesised by Geneworks (Hindmarsh, SA, Australia).

Standard curves were created to quantify absolute copy numbers for each gene. Briefly, positive PCR samples were pooled, DNA purified, a ligation reaction set up using the pGEM-T Easy Vector System (Promega) and $\alpha$-Select Bronze Efficiency competent cells (Bioline, Alexandria, Australia) were transformed, inoculated onto LB agar and incubated overnight. A single colony was selected and cultured overnight in LB broth. Plasmid DNA was extracted from the overnight culture.
After extraction, the plasmid was sent for sequencing to Monash Micromon (Melbourne, Australia) to confirm the sequence of the insert before dilution series were generated based on plasmid DNA concentration and size. Standard curves containing ten-fold dilutions from 30000000 to 300 copies per $5 \mu \mathrm{L}$ were created for each gene.

Quantitative real-time PCRs were performed using the Rotor-Gene Q PCR machine (Qiagen). Each $20 \mu \mathrm{L}$ reaction was set up with $10 \mu \mathrm{L}$ iTaq Universal SYBR Green Supermix (Bio-Rad), $1 \mu \mathrm{L}$ of each primer (forward and reverse, $10 \mu \mathrm{M}$ ), $3 \mu \mathrm{L}$ RNAse-free water and $5 \mu \mathrm{L}$ cDNA. A no-template control (RNAse-free water) and the appropriate standard curves were included in each run. All samples were run in triplicate. The reactions were incubated through an initial activation and denaturation step at $95{ }^{\circ} \mathrm{C}$ for $30 \mathrm{~s}$, followed by 40 cycles of $5 \mathrm{~s}$ at $95^{\circ} \mathrm{C}$ and $30 \mathrm{~s}$ at $60^{\circ} \mathrm{C}$. A melt curve analysis was performed between 65 and $95{ }^{\circ} \mathrm{C}$ in $0.5{ }^{\circ} \mathrm{C}$ increments to confirm the identity of the amplicons.

\section{Data analysis and statistical methods}

All statistical analyses were performed using Stata release 14 (StataCorp, College Station, TX, USA). Results were considered statistically different if the value of $P$ was

Table 1 Primer sequences used for quantitative reverse transcriptase PCR

\begin{tabular}{|c|c|c|c|c|c|}
\hline Gene name & Forward primer sequence & Reverse primer sequence & Insert size (bp) & Inter-exonic & Accession number/reference \\
\hline GAPDH & GCTTCCCTTCCGCACTGCTA & CTCGGCCTTGACTGTGCCAT & 222 & Yes & NM_001163856.1 \\
\hline$\beta$-Actin & CGTGGGCCGCCCTAGGCACCA & TTGGCCTTAGGGTTCAGGGGGG & 243 & Yes & [17] \\
\hline RPL17 & TACAAAGTCATGCAAATCAAGAGGT & TTGGGAGCTTTGTTCACCTGG & 339 & Yes & NC_009151.2 \\
\hline RPL27A & AGGAAGACCCGGAAACTTCG & TTTGTAGTAGCCCGATCGCACC & 315 & Yes & NC_009150.2 \\
\hline RPL30 & GGCCGTCCCGCACCTAAG & ATGACCAGTTTCGCTTTGCCT & 166 & Yes & XM_001491150.4 \\
\hline RPL32 & TGGTCCACAATGTCAAGGAGC & TCGTCTATTCGTTTTCTTCGCTGC & 180 & No & XM_001500029.4 \\
\hline RPS5 & TGCCATCATCAACAGTGGTCC & AGGTTTATTGGGGCTGTGGTCG & 301 & Yes & XM_001495360 \\
\hline TLR2 & GTGGACGGTGTGGGTCTTAG & TGATGTCATTGGACCCCAGC & 254 & No & NM_001081796.1 \\
\hline TLR4 & CTGTTACGGTGCGTCATGCT & ACCTGCAGTTCTGGGAAGTT & 301 & Yes & NM_001099769.1 \\
\hline NLRC5 & CAGCTCCAGCACGGTATCAA & GCTAGTGTGGTCTTGCCCAT & 377 & Yes & XM_005608529.1 \\
\hline CCL2 & CAACAACTCTCAGGCCGAA & ATCTCCTTGGCCAATATGGTCT & 262 & Yes & NM_001081931.1 \\
\hline CXCL9 & AACAGTTTGCTCCAAGCCCT & CTTTTGACGAGGACGTTGCC & 221 & Yes & NM_001130078.1 \\
\hline CXCL10 & ССТCTCTCTAGAACTGCACGC & GACGGTCTTGGACTCTGGATT & 180 & Yes & NM_001114940.1 \\
\hline CXCL11 & GGCCCTGGAGTAAAAGCAGT & AACAGGCCGGAGAAAGTCAG & 301 & Yes & NM_001278930.1 \\
\hline EBD1 & ATTTTCTCCTTGCCTTCCTCAT & GATACAAGTGCCGATCTGT & 148 & Yes & {$[45]$} \\
\hline Lysozyme & TGGGTCTGTTTGGCCAGATG & GTGAGGTCGTGGTTCTGACA & 284 & Yes & XM_001494130.2 \\
\hline Lipocalin 2 & GACCACAGCTACAACGTCAC & TCAGCTCCTTGGTCCTCCTAT & 253 & Yes & XM_005605817.1 \\
\hline Lactoferrin & TGGCTGAACTCCAAGGCAAA & GCGAGCATCACTCTCAGGAA & 216 & Yes & NM_001163974.1 \\
\hline Uteroferrin & CCAATATGGTCCATCGCGGA & GGGGTCCATGAAGTTCCCAG & 180 & Yes & NM_001246672 \\
\hline SLPI & CTTCCCCCTCGTGCTTCTTG & CAATGGGGTCCAGGCATTTG & 209 & Yes & XM_005604654.1 \\
\hline P19 & TGATGACGGCTCACAAAACG & GCACCGATCAGTTTGGGTCAG & 269 & Yes & NM_001082509.2 \\
\hline sPLA2 & GTTATGGCTTCTACGGTTGCCACT & ACACCCACGTTTCTGCAGACGATA & 119 & Yes & NM_001100113.2 \\
\hline TIMP1 & CTACACCCCCGCTATGGAGA & CTGGTCCGTCCACAAGCAAT & 268 & Yes & NM_001082515.1 \\
\hline
\end{tabular}


$<0.05$. To assess the distribution of all variables, we generated frequency distributions for all categorical variables and histograms and summary measures for all continuous variables. For comparison of the presence of bacteria, a multi-level mixed-effects generalised linear model (with logit link function) was used with horse id entered as a random effect to account for repeated measurement and individual variability by horse. Data were log-transformed where appropriate.

Cycle stage comparisons were performed using interaction terms to combine time and cycle stage. The effect of the introduction of $E$. coli on clinical parameters and the expression of several genes associated with the immune response were analysed using a repeated measures ANOVA applying the Bonferroni correction for multiple comparisons. The interaction model was then used to estimate the fold change of gene expression at different time points in comparison to $0 \mathrm{~h}$, which was designated as reference category.

\section{Results}

\section{Clinical and gynaecological examination}

All mares identified as being in the dioestrus phase of the cycle were found to have plasma progesterone concentrations between 25 and $33 \mathrm{nmol} / \mathrm{L}$, as expected.

The heart and respiratory rates of all mares remained within physiological limits throughout the experiment. Rectal temperatures were increased at $12 \mathrm{~h}$ pi compared to before and $3 \mathrm{~h}$ pi $(P<0.001$; Figure 2$)$. During dioestrus, the mares had higher rectal temperatures at 3,12 and $24 \mathrm{~h}$ pi compared to their rectal temperatures after inoculation during oestrus at the same time points $(P<0.05)$. The rectal temperatures of the mares ranged between 38.7 and $39.7{ }^{\circ} \mathrm{C}$ at 12 pi in dioestrus, above the physiological range $\left(37.5-38.5{ }^{\circ} \mathrm{C}\right)$. Temperatures were within the normal range in oestrus in the same mares at the same time point (Figure 2).

Oedema scores prior to inoculation with E. coli were in category 2 and 3 in oestrus, while no oedema was detected in dioestrus. Three hours after inoculation with E. coli, an oedema score of four was detected in all horses, irrespective of cycle stage. At $12 \mathrm{~h} \mathrm{pi}$, oedema scores ranged from 2 to 4 in both cycle stages, before decreasing to a range between 1 and 3 at $48 \mathrm{~h}$ pi and between 1 and 2 at $72 \mathrm{~h}$ pi (Figure 2).

\section{Bacteriological culture}

No growth was detected prior to inoculation of $E$. coli in any of the cultures. Three hours afterwards, growth from biopsy sample cultures ranged from no to moderate growth during oestrus and from moderate to heavy growth in dioestrus, with more than $50 \mathrm{CFU} /$ sample cultured from four of five mares (Table 2). From $12 \mathrm{~h}$ until $72 \mathrm{~h}$ pi, no growth was detected from any biopsies taken in oestrus, except for one horse with moderate growth of bacteria other than $E$. coli at $72 \mathrm{~h}$ pi. In dioestrus, the numbers of bacteria remained high, with all samples yielding moderate to heavy growth $12 \mathrm{~h}$ pi. In the period from 1 to 2 days after the introduction of $E$. coli, culture yielded no to moderate growth in dioestrus samples and no growth was detected in any cultures from $72 \mathrm{~h}$ samples. Cultures of swab samples yielded comparable results, with slightly higher numbers of bacteria detected (Table 2). Overall, 8.1 times more samples obtained in dioestrus were culture positive in comparison to oestrus $(P=0.008)$ and significantly more samples obtained between 3 and $24 \mathrm{~h}$ pi were culture positive in comparison to the baseline ( $0 \mathrm{~h}$ ) (Additional file 1).

\section{Histopathology}

One sample taken in dioestrus at $24 \mathrm{~h}$ was missing and omitted from the analysis. No inflammation was detected prior to the introduction of $E$. coli in any of the samples. Three hours afterwards, the level of neutrophilia ranged from moderate to severe in dioestrus samples, while all oestrus samples had very severe levels of neutrophilia. After $12 \mathrm{~h}$, samples in both cycle stages showed signs of severe to very severe neutrophilia. At $24 \mathrm{~h}$, oestrus samples were classified as having moderate to severe neutrophilia and dioestrus samples moderate to very severe neutrophilia, with more neutrophils present in all dioestrus samples when paired with the oestrus samples from the same time point in the same horse. Neutrophils were detected in the epithelium of most samples within the first $12 \mathrm{~h}$, regardless of cycle stage, while there were fewer seen in oestrus at $24 \mathrm{~h}$ pi in two of five samples. All but one $3 \mathrm{~h}$ sample in dioestrus had neutrophils inside endometrial glands, while two oestrus samples did not have any neutrophils in this location $12 \mathrm{~h}$ pi with $E$. coli. Eosinophil counts ranged from 0 to 16 at $3 \mathrm{~h}, 1$ to 56 at $12 \mathrm{~h}$ and 0 to 33 at $24 \mathrm{~h}$ (Table 3; Figure 3 ).

\section{Endometrial gene expression}

Seven genes were tested to identify the most stable genes under the experimental conditions used for the study. Of these, GAPDH, RPL30, RPL32 and RPS5 showed no significant variation between any of the time points or cycle stages. This also confirmed that the efficiency of the cDNA synthesis was consistent between samples, allowing for gene-specific absolute quantification.

The target genes were divided into several groups based on their function in the immune system. Statistical results for gene expression levels can be found in Additional file 2 . 


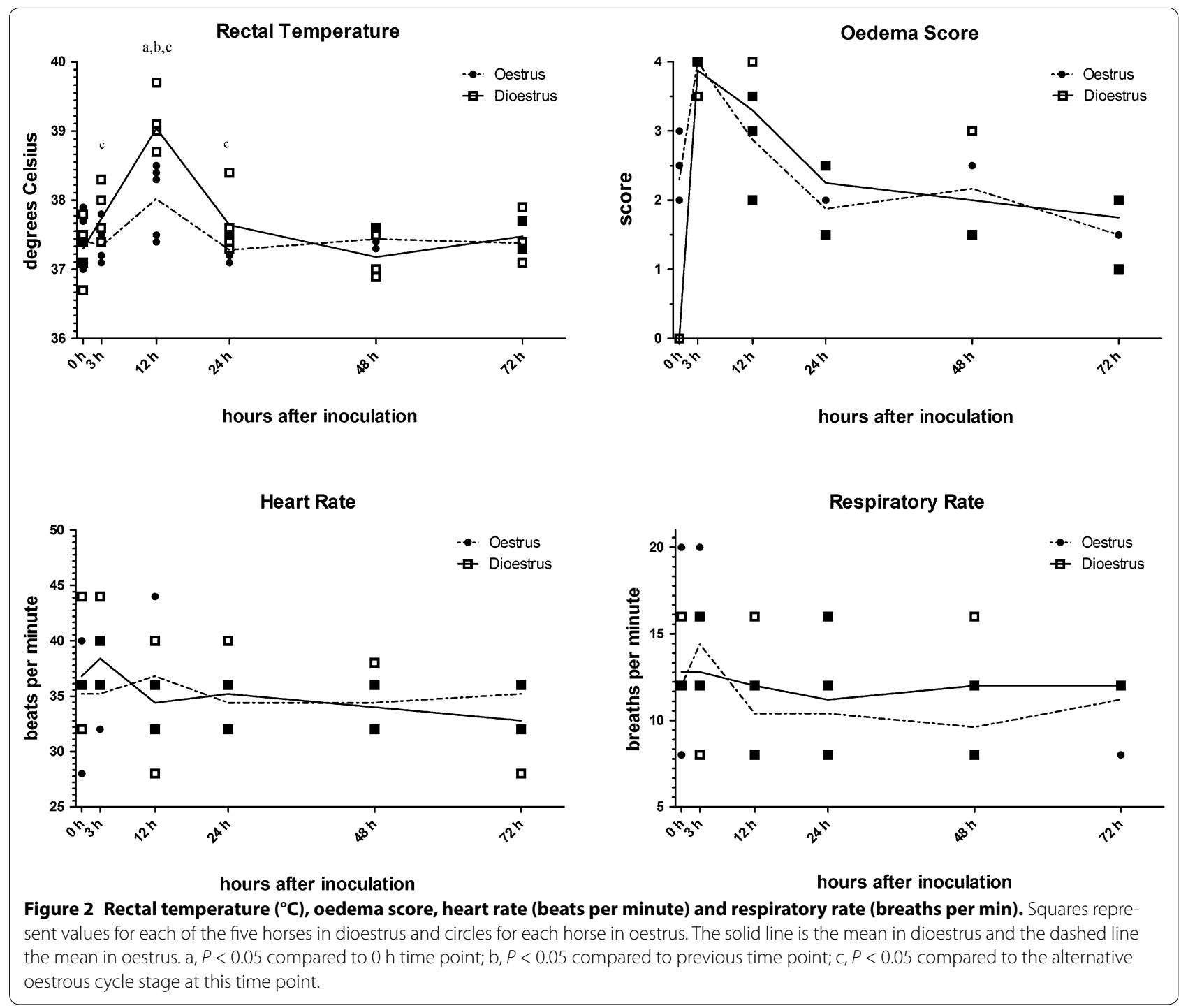

Table 2 Bacterial growth from uterine biopsies and swabs before ( $0 \mathrm{~h}$ ) and 3, 12, 24, 48 and $72 \mathrm{~h}$ after intrauterine inoculation of $E$. coli

\begin{tabular}{|c|c|c|c|c|c|c|c|c|c|c|c|c|c|}
\hline \multirow[t]{2}{*}{ Mare ID } & \multirow[t]{2}{*}{ Cycle } & \multicolumn{6}{|c|}{ Biopsy sample } & \multicolumn{6}{|c|}{ Swab sample } \\
\hline & & $\mathrm{Oh}$ & $3 \mathrm{~h}$ & $12 \mathrm{~h}$ & $24 \mathrm{~h}$ & $48 \mathrm{~h}$ & $72 \mathrm{~h}$ & $\mathrm{Oh}$ & $3 \mathrm{~h}$ & $12 \mathrm{~h}$ & $24 \mathrm{~h}$ & $48 \mathrm{~h}$ & $72 \mathrm{~h}$ \\
\hline B & Oestrus & 1 & 6 & 1 & $1^{a}$ & 0 & $2^{\mathrm{a}}$ & 0 & $>50$ & 12 & 0 & 0 & 0 \\
\hline E & Oestrus & 0 & 0 & 1 & 4 & 1 & 0 & 0 & $>50$ & 2 & 2 & 0 & 0 \\
\hline S & Oestrus & 0 & 20 & 2 & 0 & 0 & $24^{\mathrm{a}}$ & $1^{\mathrm{a}}$ & 16 & 0 & 0 & 0 & 0 \\
\hline U & Oestrus & 0 & 0 & 0 & $1^{\mathrm{a}}$ & 0 & $3^{\mathrm{a}}$ & 0 & 6 & 0 & 0 & 0 & 0 \\
\hline V & Oestrus & 0 & 4 & 0 & $1^{\mathrm{a}}$ & 0 & 2 & 0 & 3 & 1 & 0 & $>50^{\mathrm{a}}$ & 0 \\
\hline B & Dioestrus & 0 & 32 & $>50$ & 16 & 8 & 0 & 0 & $>50$ & $>50$ & 0 & 18 & 0 \\
\hline$E$ & Dioestrus & $1^{\mathrm{a}}$ & $>50$ & $>50$ & 7 & 0 & 0 & 0 & $>50$ & $>50$ & $>50$ & 0 & 0 \\
\hline S & Dioestrus & 0 & $>50$ & 50 & 28 & 11 & 0 & 0 & $>50$ & $>50$ & 51 & 9 & 0 \\
\hline U & Dioestrus & 0 & $>50$ & $>50$ & 8 & 4 & 0 & 0 & $>50$ & $>50$ & 43 & 14 & 2 \\
\hline V & Dioestrus & 0 & $>50$ & 15 & 2 & 3 & 0 & 0 & $>50$ & 3 & 0 & 0 & 0 \\
\hline
\end{tabular}

a Other uterine pathogen and/or contamination (lactose negative on MacConkey agar). 
Table 3 Leukocyte counts (neutrophils and eosinophils) before $(0 \mathrm{~h})$ and 3, 12 and $24 \mathrm{~h}$ after intrauterine inoculation of E. coli

\begin{tabular}{|c|c|c|c|c|c|c|c|c|c|}
\hline \multirow[t]{2}{*}{ Mare ID } & \multirow[t]{2}{*}{ Cycle } & \multicolumn{4}{|c|}{ Neutrophils } & \multicolumn{4}{|c|}{ Eosinophils } \\
\hline & & $\mathrm{Oh}$ & $3 \mathrm{~h}$ & $12 \mathrm{~h}$ & $24 \mathrm{~h}$ & $\mathrm{Oh}$ & $3 \mathrm{~h}$ & $12 \mathrm{~h}$ & $24 \mathrm{~h}$ \\
\hline B & Oestrus & 7 (Ep1, G0) & $>150(\mathrm{Ep} 3, \mathrm{G} 1)$ & 110 (Ep2, G0) & 60 (Ep1, G0) & 2 & 10 & 1 & 0 \\
\hline$E$ & Oestrus & 1 (Ep0, G0) & $>150(\operatorname{Ep} 3, \mathrm{G} 2)$ & $110($ Ep3, G0) & 75 (Ep2, G0) & 3 & 15 & 10 & 22 \\
\hline S & Oestrus & 7 (Ep0, G0) & $>150(\operatorname{Ep} 3, \mathrm{G} 1)$ & $>150(\mathrm{Ep} 3, \mathrm{G} 3)$ & $80(\mathrm{Ep} 3, \mathrm{G} 2)$ & 0 & 16 & 1 & 4 \\
\hline U & Oestrus & 5 (Ep0, G0) & $>150(E p 3, G 3)$ & $>150($ Ep3, G1) & 130 (Ep3, G0) & 1 & 14 & 23 & 8 \\
\hline V & Oestrus & 8 (Ep1, G0) & $>150($ Ep3, G2) & $>150(\mathrm{Ep} 3, \mathrm{G} 2)$ & 130 (Ep3, G3) & 1 & 16 & 2 & 1 \\
\hline B & Dioestrus & 2 (Ep0, G0) & 80 (Ep1, G0) & 120 (Ep3, G1) & 90 (Ep3, G0) & 0 & 0 & 56 & 7 \\
\hline$E$ & Dioestrus & 4 (Ep0, G0) & $125($ Ep3, G3) & 140 (Ep3, G2) & 140 (Ep3, G0) & 1 & 6 & 15 & 8 \\
\hline S & Dioestrus & 7 (Ep0, G0) & $130(\mathrm{Ep} 3, \mathrm{G} 1)$ & $>150($ Ep3, G3) & $>150(\mathrm{Ep} 3, \mathrm{G} 2)$ & 2 & 0 & 35 & 28 \\
\hline U & Dioestrus & $6(E p 2$, G0) & $145($ Ep3, G3) & $>150(\mathrm{Ep} 3, \mathrm{G} 3)$ & & 0 & 14 & 21 & \\
\hline V & Dioestrus & $7(\mathrm{Ep0}, \mathrm{G} 1)$ & 145 (Ep3, G3) & $>150($ Ep3, G3) & $>150($ Ep3, G3) & 4 & 6 & 14 & 33 \\
\hline
\end{tabular}

Ep, presence of neutrophils in epithelium in 1, 2 or 3 fields.

$\mathrm{G}$, presence of neutrophils in endometrial glands in 1,2 or 3 field.

\section{Pathogen recognition receptors}

The mRNA expression levels of the genes for the pathogen recognition receptors TLR2, TLR4 and NLRC5 were two to four times higher at $3 \mathrm{~h}$ pi compared to levels before inoculation. The levels of expression of these genes decreased to baseline between 12 and $24 \mathrm{~h}$ pi (Table 4; Figure 4).

\section{Chemokines}

There was an increase in expression of all four chemokine genes analysed at $3 \mathrm{~h}$ pi, with levels starting to decrease between 12 and $24 \mathrm{~h}$ pi and reaching pre-inoculation levels at $72 \mathrm{~h}$ pi. Peak expression levels ranged between 126 and 443 times that of the respective baseline levels and were reached at $3 \mathrm{~h}$ pi for CCL2, CXCL10 and CXCL11 and at $12 \mathrm{~h}$ pi for CXCL9 (Table 4; Figure 5).

\section{Tissue inhibitors of metallopeptidases}

The levels of expression of the gene for the metallopeptidase inhibitor TIMP-1 increased to 32 times baseline levels at $3 \mathrm{~h}$ after inoculation of $E$. coli and remained elevated throughout the experimental period (Table 4; Figure 4).

\section{Antimicrobial peptides}

Expression profiles of genes for antimicrobial peptides exhibited greater variability in response to $E$. coli (Table 5; Figure 6). While most genes were expressed at higher levels between 3 and $12 \mathrm{~h}$ after inoculation compared to baseline, expression of P19 and sPLA $\mathrm{A}_{2}$ remained unchanged. The greatest difference between oestrus and dioestrus expression profiles was seen at $12 \mathrm{~h}$ pi. Genes for LCN2, UFN and SLPI were expressed at higher levels in dioestrus, while the gene for LFN was expressed at higher levels in oestrus at this time point.
EBD-1 gene expression did not differ between cycle stages. There was a very rapid increase from levels of between 0 and 5 copies/ng of RNA prior to inoculation of E. coli to levels of between 3488 and 96657 copies/ng of RNA at $12 \mathrm{~h}$ after inoculation.

The expression of the lysozyme gene was increased to 42 times baseline at $3 \mathrm{~h}$ pi and remained at a similar level until $24 \mathrm{~h}$ pi, after which levels decreased.

No significant difference in expression was detected for the $\mathrm{SPLA}_{2}$ gene either over time or between cycle stages, with levels averaging 109409 copies/ng of RNA.

SLPI gene expression increased to more than 15000 times baseline at $12 \mathrm{~h}$ pi, before slowly decreasing. Gene expression started with higher levels in oestrus compared to dioestrus, but dioestrus levels were higher than oestrus levels at 12 and $24 \mathrm{~h}$ pi. At $48 \mathrm{~h}$ pi the level of expression was similar in both oestrus and dioestrus samples, but oestrus levels were higher at $72 \mathrm{~h}$ pi.

Expression of the LCN2 gene increased to 72 times baseline levels at $12 \mathrm{~h}$ pi, before slowly declining. The levels of expression were higher in dioestrus at $12 \mathrm{~h} \mathrm{pi}$, compared to in oestrus.

The increase in gene expression of the LFN gene was continuous, reaching 14.7 times baseline levels at $72 \mathrm{~h}$ pi. While LFN gene expression in oestrus was higher throughout the first $48 \mathrm{~h}$ pi, dioestrus levels were higher at $72 \mathrm{~h} \mathrm{pi}$.

UFN gene expression increased to 7.2 times higher than baseline levels at $3 \mathrm{~h}$ pi in both cycle stages. At $12 \mathrm{~h}$ after the introduction of $E$. coli, expression remained at similar levels in dioestrus samples. By $24 \mathrm{~h}$, oestrus and dioestrus levels of mRNA for the UFN gene were similar and did not differ from those in baseline samples.

Expression of the P19 gene did not change over the first $48 \mathrm{~h}$ pi, but then decreased to levels 43 times lower than baseline. Dioestrus levels higher before and at 3 and $12 \mathrm{~h}$ pi. 

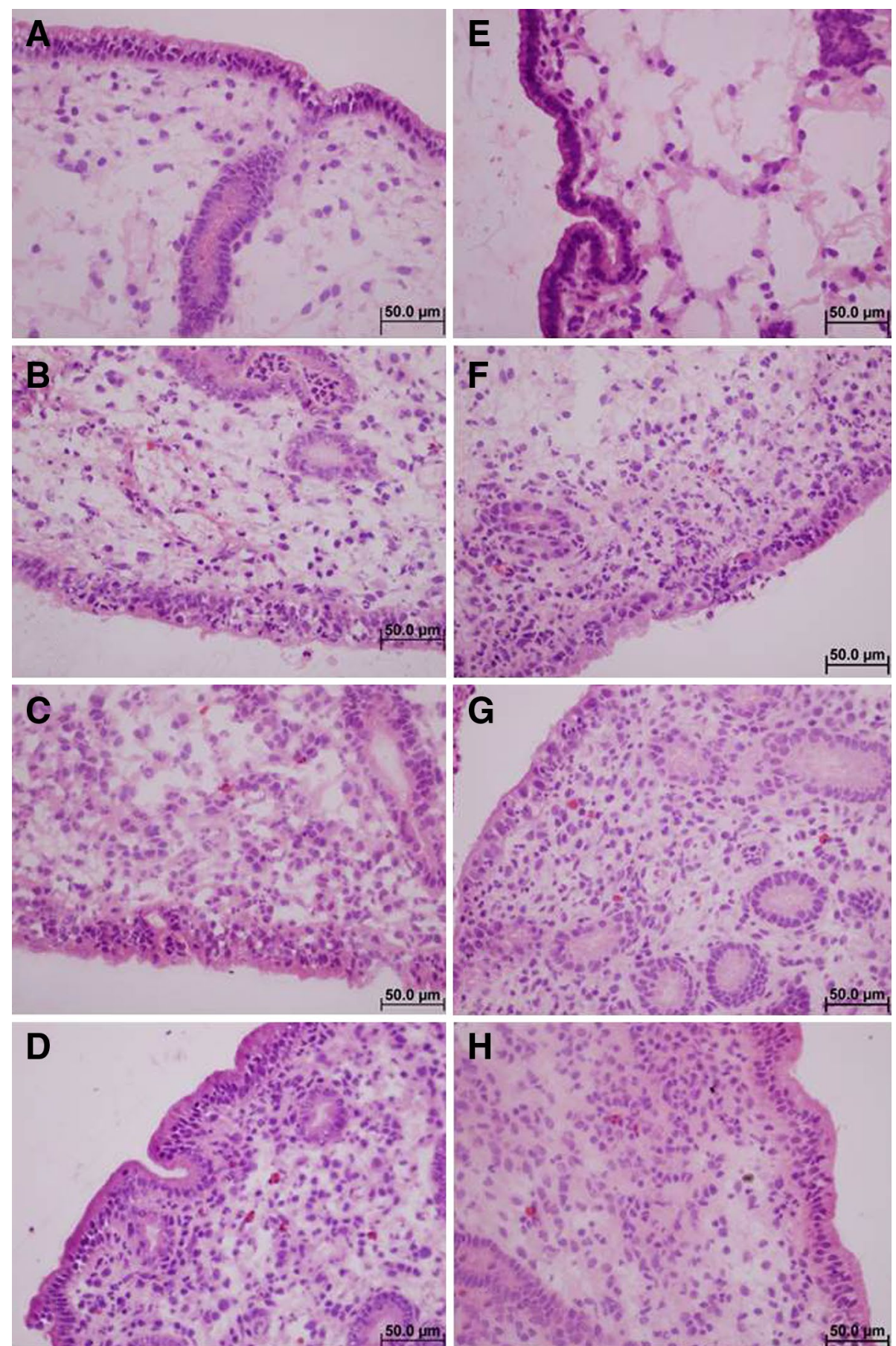

Figure 3 Histology images of one horse. Representative histology images of one horse obtained from biopsies taken in dioestrus (A-D), A before and at $\mathbf{B} 3 \mathrm{~h}, \mathbf{C} 12 \mathrm{~h}$ and $\mathbf{D} 24 \mathrm{~h}$ after inoculation of $E$. coli and in oestrus (E-F), E before and at $\mathbf{F} 3 \mathrm{~h}, \mathbf{G} 12 \mathrm{~h}$ and $\mathbf{H} 24 \mathrm{~h}$ after inoculation of $E$. coli at $\times 400$ magnification.

\section{Discussion}

Many broodmares are affected by persistent endometritis, a disease that has been identified as the third most common medical problem in American horses [47], and results in reduced pregnancy rates [2]. Both breeding and the introduction of bacteria have been shown to induce an inflammatory response in the equine uterus $[14,42,48]$. Thus, the first step to understanding the 
Table 4 Linear mixed regression coefficients and confidence intervals for all statistically significantly different comparisons between time points after inoculation with $E$. coli and baseline $(0 \mathrm{~h})$ for pathogen recognition receptors, chemokines and tissue inhibitor of metallopeptidase 1

\begin{tabular}{|c|c|c|c|c|c|}
\hline Group & Gene & Time (h) & $P$ value & Contrast & $(95 \% \mathrm{Cl})$ \\
\hline \multirow[t]{8}{*}{ Pathogen recognition receptors } & TLR2 & 3 & $<0.001$ & 4.3 & $(2.7,7)$ \\
\hline & & 12 & 0.005 & 2.0 & $(1.2,3.2)$ \\
\hline & TLR4 & 3 & $<0.001$ & 5.5 & $(3.4,9.1)$ \\
\hline & & 12 & 0.006 & 2.0 & $(1.2,3.3)$ \\
\hline & & 48 & 0.007 & 0.5 & $(0.3,0.8)$ \\
\hline & & 72 & 0.022 & 0.6 & $(0.3,0.9)$ \\
\hline & NLRC5 & 3 & 0.018 & 2.3 & $(1.2,4.5)$ \\
\hline & & 12 & 0.010 & 2.5 & $(1.2,4.9)$ \\
\hline \multirow[t]{16}{*}{ Chemokines } & CCL2 & 3 & $<0.001$ & 257.3 & $(126.2,524.3)$ \\
\hline & & 12 & $<0.001$ & 13.9 & $(6.8,28.3)$ \\
\hline & & 24 & $<0.001$ & 4.4 & $(2.2,9)$ \\
\hline & & 48 & 0.001 & 3.3 & $(1.6,6.8)$ \\
\hline & CXCL9 & 3 & $<0.001$ & 25.5 & $(12.6,51.5)$ \\
\hline & & 12 & $<0.001$ & 126.6 & $(62.7,255.6)$ \\
\hline & & 24 & $<0.001$ & 41.0 & $(20.3,82.8)$ \\
\hline & & 48 & $<0.001$ & 6.6 & $(3.3,13.4)$ \\
\hline & CXCL10 & 3 & $<0.001$ & 442.7 & $(189.2,1035.4)$ \\
\hline & & 12 & $<0.001$ & 228.1 & $(97.5,533.5)$ \\
\hline & & 24 & $<0.001$ & 17.2 & $(7.4,40.2)$ \\
\hline & & 48 & $<0.001$ & 4.6 & $(2,10.9)$ \\
\hline & CXCL11 & 3 & $<0.001$ & 116.4 & $(45.1,301)$ \\
\hline & & 12 & $<0.001$ & 388.7 & $(150.4,1004.6)$ \\
\hline & & 24 & $<0.001$ & 23.0 & $(8.9,59.5)$ \\
\hline & & 48 & $<0.001$ & 8.5 & $(3.3,22)$ \\
\hline \multirow[t]{5}{*}{ Tissue inhibitor of matrix metallo-peptidases } & TIMP1 & 3 & $<0.001$ & 31.7 & $(14.1,71.5)$ \\
\hline & & 12 & $<0.001$ & 27.8 & $(12.4,62.7)$ \\
\hline & & 24 & $<0.001$ & 7.4 & $(3.3,16.7)$ \\
\hline & & 48 & 0.002 & 3.6 & $(1.6,8.2)$ \\
\hline & & 72 & $<0.001$ & 10.9 & $(4.9,24.6)$ \\
\hline
\end{tabular}

Contrasts represent back-transformed regression coefficients for multiplicative interpretation. Time, time point in hours (h) after inoculation of $E$. coli.

$\mathrm{Cl}$ : confidence interval.

pathophysiological mechanisms underlying the diseases is to analyse the precise timeline of the inflammatory response in the equine uterus during infectious endometritis in healthy mares. In addition, the evaluation of the impact the different hormonal environments associated with the oestrous cycle have on this process, may provide further insights into the use of experimental inoculation with $E$. coli as a model of infectious endometritis. As the uterine bacterial load during PMIE is unknown, a relatively high dose was used in this experiment in order to reliably induce a measurable immune response in mares resistant to PMIE [7]. The bacterial growth detected during these studies showed that infection was reliably induced in both cycle stages and that it was cleared within the $72 \mathrm{~h}$ study period (Table 2), suggesting an appropriate dose of $E$. coli was used. The clinical and gynaecological examinations (Figure 2), as well as the histological cell counts (Figure 3; Table 3), confirmed that transient inflammation was induced in all horses. The combination of a significant increase in body temperature $12 \mathrm{~h}$ pi, inflammatory uterine oedema at $3 \mathrm{~h}$ pi and a rapid influx of neutrophils within the first $3 \mathrm{~h}$ pi were clearly indicative of this. Similarly, the expression of most of the analysed genes associated with the innate immune system was up-regulated between 3 and $12 \mathrm{~h}$ pi.

It was assumed that the effect of collection of repeated biopsies in the same cycle was negligible compared to the strong reaction to $E$. coli, particularly as previous studies have detected no effect of repeated biopsies on expression of a range of cytokines [7]. The fact that monocultures of E. coli were detected in most of the cultured biopsy and swab samples renders a contamination of the uterus with 

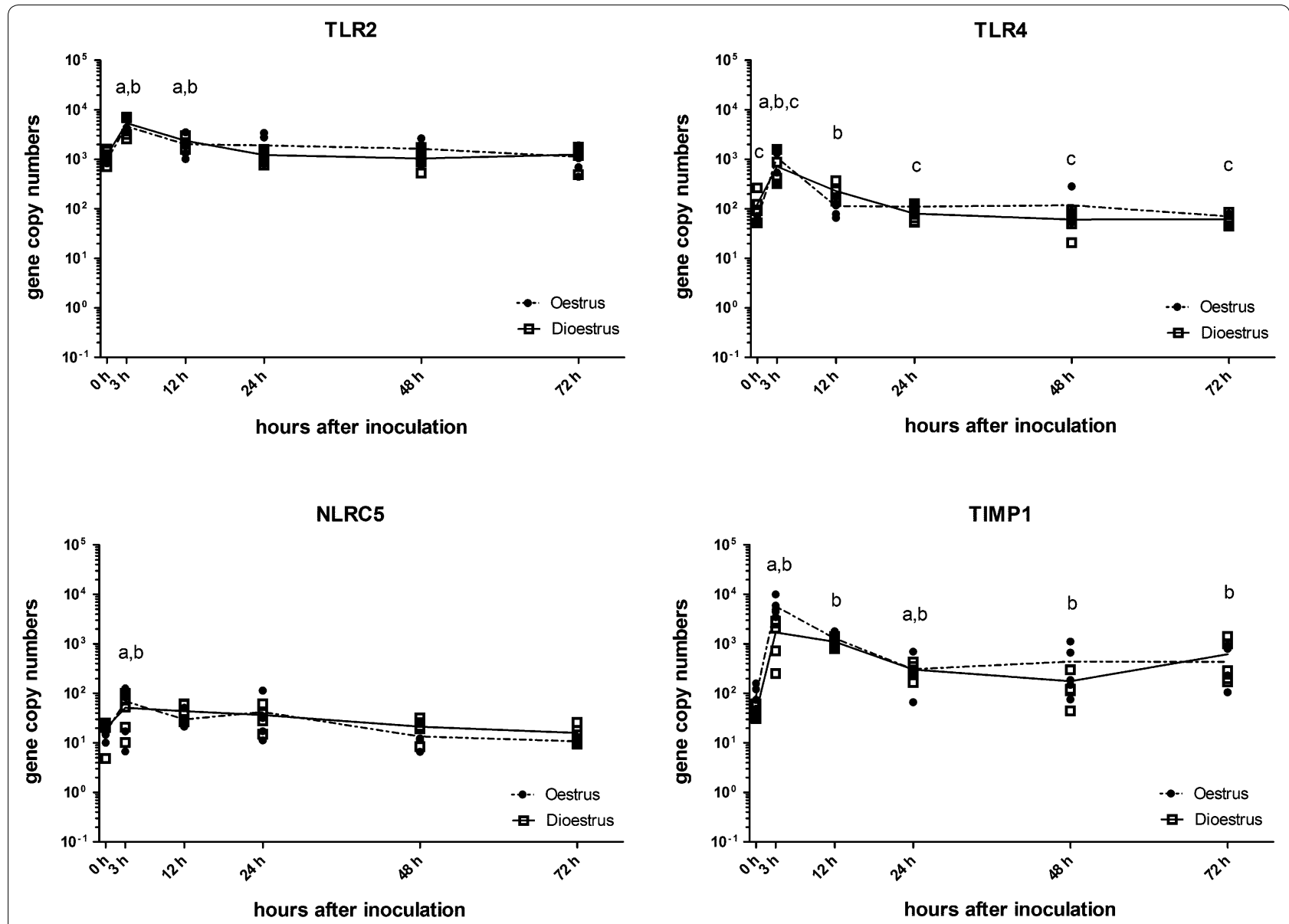

Figure 4 Levels of mRNA transcripts of endometrial TLR2, TLR4, NLRC5 and TIMP1 genes. Gene expression was measured in copy numbers/ng RNA determined from standard curves for each gene. Squares indicate values for each of the five horses in dioestrus and circles for each horse in oestrus. The solid line is the mean in dioestrus and the dashed line the mean in oestrus. a, $P<0.05$ compared to $0 \mathrm{~h}$ time point; $b, P<0.05$ compared to previous time point; $c, P<0.05$ compared to the alternative oestrus cycle stage at this time point.

additional bacteria unlikely as these introduced bacteria would have reached detectable levels by the next sample collection. While we cannot entirely exclude an inflammatory effect of the repeated tissue disruption, most gene expression levels in this study returned to baseline levels within 24-72 h pi despite repeated biopsy collection. Alternatively, samples could have been collected in different cycles, which would have introduced more variability regarding individual changes throughout the breeding season, or from different horses, which would have increased the bias from biological inter-individual variations.

Our previous next-generation sequencing analysis revealed that a large number of immune response genes were up-regulated within the first $3 \mathrm{~h}$ after the introduction of $E$. coli into the uterus [18]. To investigate the progression of the inflammatory response after this time point, expression of a panel of genes was followed by qPCR until $72 \mathrm{~h}$ after inoculation. This revealed that expression of most of the analysed innate immune response genes increased very rapidly in response to the introduction of bacteria, but that levels declined to baseline or nearly baseline within $48-72 \mathrm{~h}$. The mRNA expression profiles for the initial $3 \mathrm{~h}$ pi provide very similar results to our previous deep-sequencing analysis validating both techniques [18].

\section{Pathogen recognition receptors}

When $E$. coli enters the body, its LPS is detected by PRR, particularly TLR4 $[20,21]$. Our results showed that transcripts of the TLR4 gene were present in the uterus of all five mares in both stages of the oestrous cycle prior to inoculation. The introduction of $E$. coli resulted in a significant increase in gene expression by $3 \mathrm{~h}$ pi, but expression returned to baseline levels by $12 \mathrm{~h}$ pi. As activation of cells through TLR4 ultimately leads to an increase in cytokine production [20] and prolonged inflammation is undesirable in the uterus, this very rapid, but shortlived, up-regulation in mRNA levels at the initial point of 


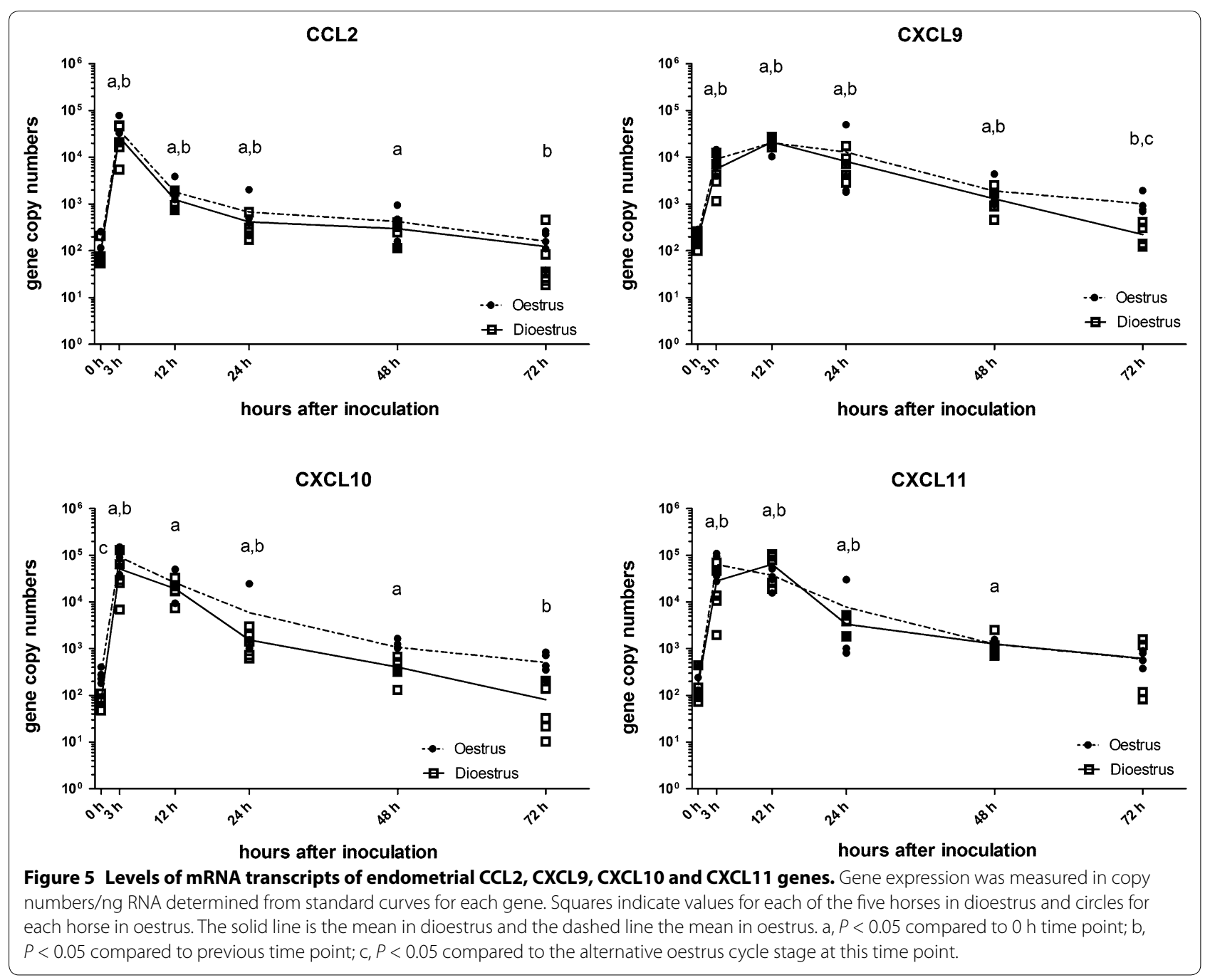

detection is likely to be necessary for effective elimination of bacteria. Similarly, the expression of the TLR2 gene, which has a supportive role in detection of LPS [22], is only up-regulated for the first $12 \mathrm{~h}$ pi. The function of NLRC5 has been described as inhibiting pro-inflammatory cytokine production [49], but also as inducing their expression through the inflammasome complex [50]. We found that the expression of the NLRC5 gene was slightly up-regulated $3 \mathrm{~h}$ after the introduction of $E$. coli, suggesting a pro-inflammatory role. All three PRR genes had very similar patterns of expression over time, with the TLR4 gene showing the greatest increase in response to E. coli (Figure 4). Surprisingly, the expression of the PRR genes in response to $E$. coli did not differ greatly between oestrus and dioestrus.

\section{Chemokines}

Chemokines are produced by sentinel cells, such as macrophages, in response to activation through PRRs on their cell surface. They are a subfamily of cytokines recruiting various leucocytes, such as monocytes by CCL2, and T lymphocytes by CXCL9, 10 and 11 [5154]. In addition, CXCL9, 10 and 11 have been suggested to have antimicrobial activities [25, 26, 55]. We found that the mRNA levels of all analysed chemokines were elevated as early as $3 \mathrm{~h}$ after the introduction of $E$. coli into the uterus, reaching a peak expression levels between 3 and $12 \mathrm{~h}$ after infection and only decreasing to baseline levels at $72 \mathrm{~h}$ pi (Figure 5). CCL2 gene expression decreased already between 3 and $12 \mathrm{~h}$, while levels of expression of the CXCL9, 10 and 11 genes were still high at $12 \mathrm{~h}$ pi. CCL2 was also the only chemokine analysed that has no direct antimicrobial effect on E. coli, with the other three CXCL chemokines able to kill $60-80 \%$ of cultured $E$. coli [26]. Thus, a longer up-regulation of CXCL9, 10 and 11 may be more beneficial in aiding the clearance of $E$. coli from the uterus. 
Table 5 Linear mixed regression coefficients and confidence intervals for all statistically significantly different comparisons between time points after inoculation with $E$. coli and baseline $(0 \mathrm{~h})$ for antimicrobial peptides

\begin{tabular}{|c|c|c|c|c|c|}
\hline Group & Gene & Time (h) & $P$ value & Contrast & $(95 \% \mathrm{Cl})$ \\
\hline \multirow{31}{*}{$\begin{array}{l}\text { Antimi- } \\
\text { crobial } \\
\text { peptides }\end{array}$} & \multirow[t]{5}{*}{ EBD1 } & 3 & $<0.001$ & 1185.8 & $(239.8,5863)$ \\
\hline & & 12 & $<0.001$ & 65950.5 & $\begin{array}{l}(13339,326 \\
071.6)\end{array}$ \\
\hline & & 24 & $<0.001$ & 7309.0 & $\begin{array}{c}(1478.3,36 \\
137.1)\end{array}$ \\
\hline & & 48 & $<0.001$ & 580.3 & $(117.4,2869.3)$ \\
\hline & & 72 & $<0.001$ & 102.3 & $(20.7,505.6)$ \\
\hline & \multirow[t]{5}{*}{ Lysozyme } & 3 & $<0.001$ & 41.5 & $(19.8,87)$ \\
\hline & & 12 & $<0.001$ & 23.6 & $(11.3,49.4)$ \\
\hline & & 24 & $<0.001$ & 40.1 & $(19.2,84.1)$ \\
\hline & & 48 & $<0.001$ & 19.4 & $(9.3,40.7)$ \\
\hline & & 72 & 0.001 & 3.6 & $(1.7,7.5)$ \\
\hline & \multirow[t]{5}{*}{ SLPI } & 3 & $<0.001$ & 510.8 & $(173.1,1507.9)$ \\
\hline & & 12 & $<0.001$ & $15,661.6$ & $\begin{array}{c}(5305.8,46 \\
229.3)\end{array}$ \\
\hline & & 24 & $<0.001$ & 1283.8 & $(434.9,3789.6)$ \\
\hline & & 48 & $<0.001$ & 408.6 & $(138.4,1206)$ \\
\hline & & 72 & $<0.001$ & 197.9 & $(67,584.1)$ \\
\hline & \multirow[t]{5}{*}{ LCN2 } & 3 & $<0.001$ & 9.4 & $(3.7,23.8)$ \\
\hline & & 12 & $<0.001$ & 71.6 & $(28.2,182.2)$ \\
\hline & & 24 & $<0.001$ & 64.4 & $(25.3,163.8)$ \\
\hline & & 48 & $<0.001$ & 20.4 & $(8,51.9)$ \\
\hline & & 72 & $<0.001$ & 19.3 & $(7.6,49)$ \\
\hline & \multirow[t]{3}{*}{ LFN } & 24 & $<0.001$ & 6.3 & $(2.7,15.1)$ \\
\hline & & 48 & $<0.001$ & 8.1 & $(3.4,19.4)$ \\
\hline & & 72 & $<0.001$ & 14.7 & $(6.2,34.9)$ \\
\hline & \multirow[t]{4}{*}{ UFN } & 3 & $<0.001$ & 7.2 & $(2.8,18.6)$ \\
\hline & & 12 & $<0.001$ & 9.2 & $(3.6,23.7)$ \\
\hline & & 24 & 0.035 & 2.8 & $(1.1,7.1)$ \\
\hline & & 72 & 0.014 & 3.3 & $(1.3,8.4)$ \\
\hline & \multirow[t]{4}{*}{ P19 } & 12 & 0.006 & 0.2 & $(0,0.6)$ \\
\hline & & 24 & 0.002 & 0.1 & $(0,0.5)$ \\
\hline & & 48 & $<0.001$ & 0.1 & $(0,0.3)$ \\
\hline & & 72 & $<0.001$ & 0.0 & $(0,0.1)$ \\
\hline
\end{tabular}

Contrasts represent back-transformed regression coefficients for multiplicative interpretation.

Time, time point in hours (h) after inoculation of E. coli.

$\mathrm{Cl}$ : confidence interval.

\section{Tissue inhibitor of metallopeptidases}

TIMP1 regulates the expression of MMPs, thus indirectly having an inhibitory effect on the immune response. It has been shown that TIMP1 levels are reduced in human decidua prior to parturition, resulting in increased MMP levels and increased cytokine release $[56,57]$. In the equine uterus, MMPs have only been investigated for the potential role in periglandular fibrosis and endometriosis [58]. Our next-generation sequencing study was the first to associate MMP gene expression with uterine inflammation in horses and also the first to detect TIMP1 gene expression in the equine uterus [18]. Its expression reached peak levels $3 \mathrm{~h}$ pi (Figure 4). This may suggest that mechanisms for the containment of the inflammatory process are already prepared $3 \mathrm{~h}$ after the introduction of $E$. coli into the uterine environment. Interestingly, levels of expression remained elevated throughout the study period in both cycle stages, suggesting a continuous suppressive influence throughout the inflammatory process irrespective of the stage of the oestrus cycle.

\section{Antimicrobial peptides}

AMP are small peptides of less than 100 amino acids that have various antimicrobial actions and have been detected in multiple organs in the horse [27]. One bactericidal mechanism is to destabilise the bacterial cell membrane either by formation of pores in the lipid bilayer or by enzymatic degradation of the phospholipids [28]. Similar mechanisms are used by lysozyme, sPLA $_{2}$ and probably EBD1. Both human $\beta$-defensins and equine lysozyme have been shown to have bactericidal effects on Gram-negative bacteria [59, 60]. No study has evaluated the antimicrobial potency or mode of action of EBD1. In contrast, sPLA $A_{2}$, the gene for which was analysed in this study and which is in Group2A of the phospholipases (PLA2G2A) has no bactericidal activity against Gram-negative bacteria, including $E$. coli [61]. We found that expression of the EBD1 gene was more than 65000 times higher at $12 \mathrm{~h}$ after infection compared to baseline levels. Lysozyme gene expression only increased 42 times within the first $3 \mathrm{~h}$ pi. In contrast, sPLA $\mathrm{A}_{2}$ was constitutively expressed at high levels of around 100000 copies/ng of RNA (Figure 6). A previous study has detected high levels of sPLA $\mathrm{A}_{2}$ in the uterus of non-pregnant mares, with lower levels of expression seen in normal pregnant mares and increasing levels, similar to those detected in non-pregnant mares, during induced abortions [62]. The great variance in gene expression profiles within this group of AMP suggests that the uterine immune system can react in a specific and finely-tuned manner to the introduction of bacteria. While the EBD1 gene had by far the greatest increase in expression, its post inoculation expression levels were comparable to those of lysozyme and sPLA $\mathrm{A}_{2}$. In contrast, sPLA $_{2}$ levels did not increase, but were already high prior to the introduction of $E$. coli. Hence, up-regulation of EBD-1 gene expression in response to the introduction of $E$. coli may only be necessary because it is expressed at such low levels prior to stimulation. Expression of the $\mathrm{sPLA}_{2}$ gene may not be stimulated by E. coli 
EBD1

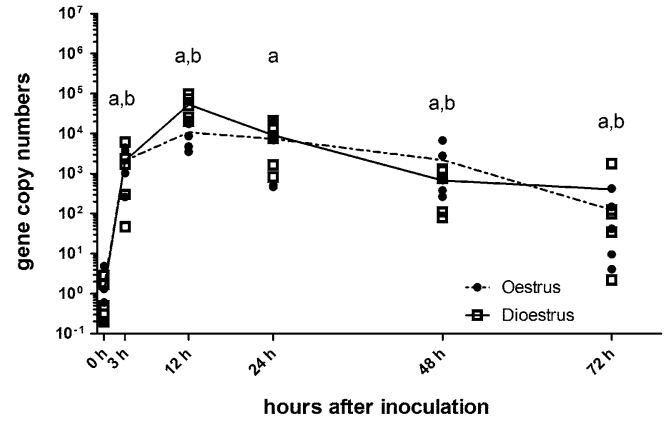

sPLA2

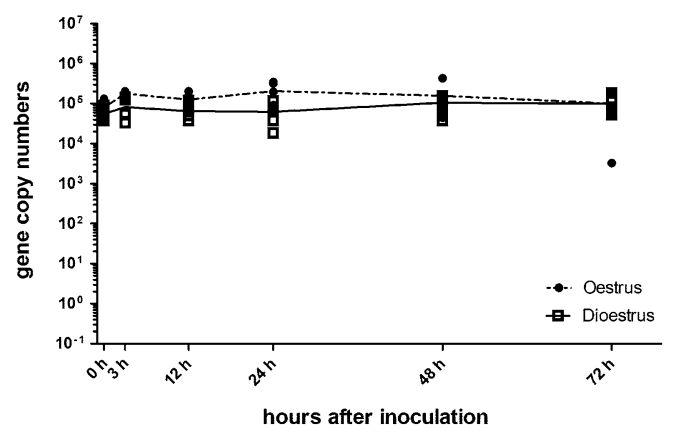

LCN 2

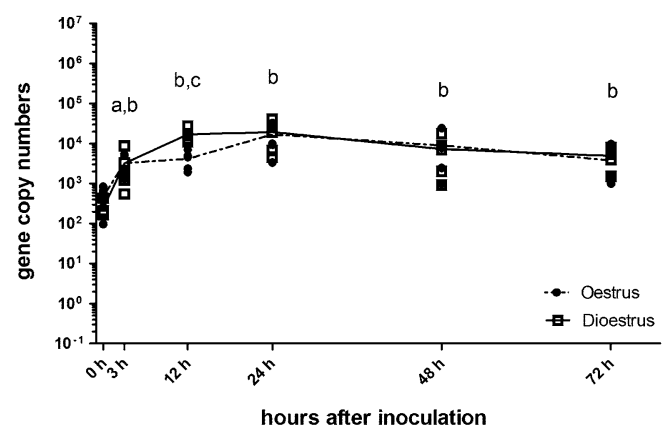

Uteroferrin

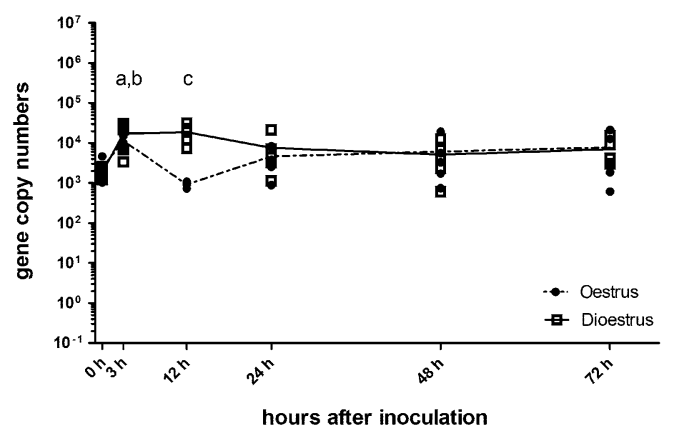

Lysozyme

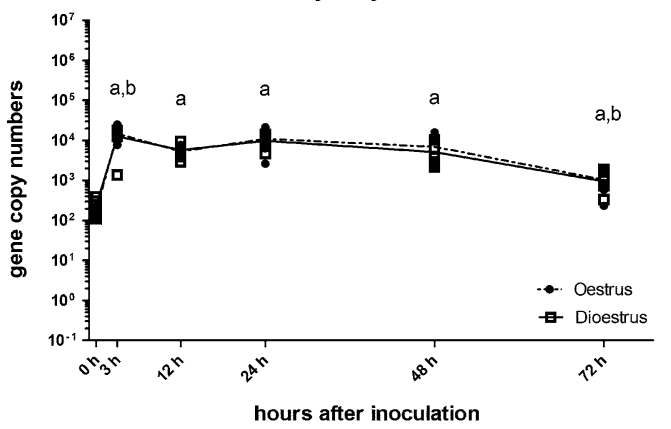

SLPI

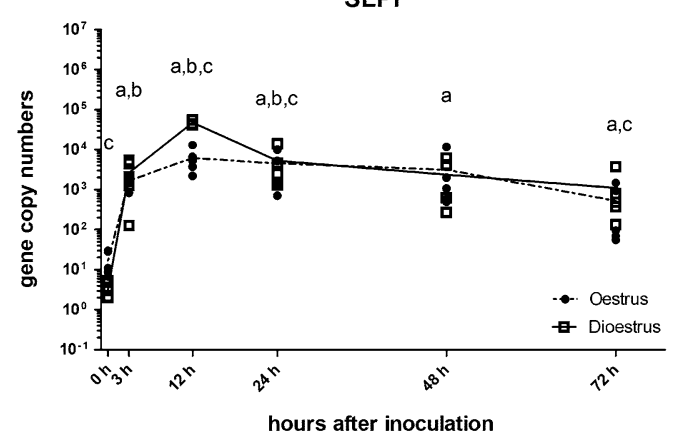

Lactoferrin

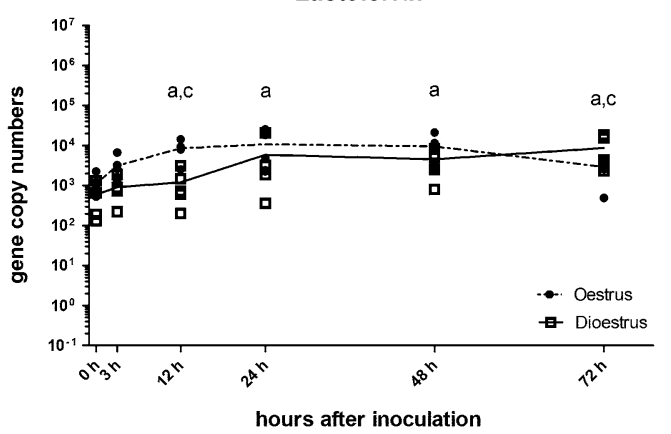

P19

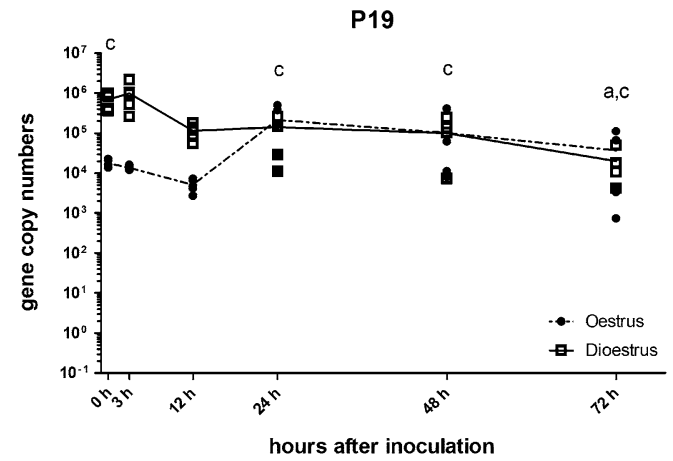

Figure 6 Levels of mRNA transcripts of EBD1, lysozyme, sPLA2, SLPI, LCN2, lactoferrin, uteroferrin and P19 uterocalin genes. Gene expression was measured in copy numbers/ng RNA determined from standard curves for each gene. Squares indicate values for each of the five horses in dioestrus and circles for each horse in oestrus. The solid line is the mean in dioestrus and the dashed line the mean in oestrus. a, $P<0.05$ compared to $0 \mathrm{~h}$ time point; $\mathrm{b}, P<0.05$ compared to previous time point; $c, P<0.05$ compared to the alternative oestrus cycle stage at this time point. 
because Gram-negative bacteria are not the primary targets of its antimicrobial activity. The stimulation of expression of the EBD1 gene by E. coli may suggest that EBD1 has antimicrobial activity against this pathogen.

SPLI has bactericidal activity against both Gram-positive and Gram-negative bacteria, selectively inhibiting serine proteases of the subtilisin superfamily, which are uniquely expressed by fungi and bacteria [32]. Expression of the SPLI gene had increased to more than 15000 times that of baseline levels by $12 \mathrm{~h}$ after the introduction of $E$. coli. SLPI gene transcription was induced by $E$. coli during both cycle stages, but at greater levels during dioestrus. One possible explanation for this is that the adaptive immune response has to be down-regulated in order to protect a potential half-allogenic conceptus from being attacked by the immune response. Hence, the innate immune response, or parts thereof, have to be more alert to compensate for this and still allow successful prevention of any possible infections.

Finally, LCN2, LFN, UFN and P19 have all been shown to bind elements such as iron, either as part of the immune response or in a trans-placental transporter function [33, 34, 37, 38]. In this study, the LCN2 and UFN genes had relatively similar expression profiles, reaching peak expression levels $12 \mathrm{~h}$ pi and with higher levels reached at this time point in dioestrus than in oestrus. In contrast, the expression of the LFN gene increased slowly and continuously, with levels 15 times higher than the baseline at $72 \mathrm{~h}$ pi and oestrus levels being higher than dioestrus levels at $12 \mathrm{~h}$ pi. The P19 uterocalin gene was initially expressed at levels 37 times higher in dioestrus than in oestrus, but this difference was eliminated by $24 \mathrm{~h}$ pi (Figure 6). The bacteriostatic effect of these binding elements may explain the slower response and the lesser magnitude of the increase in expression of this group of AMP genes compared to those of some of the other genes that encode bactericidal factors. LCN2 has been suggested previously as a marker for the response to tissue injuries or insults, including the introduction of PAMPs [63]. While uteroferrin has not been described previously as part of the uterine immune arsenal, the significant upregulation of its gene in response to infection with $E$. coli suggests that it may play a role. Contrarily, expression of the P19 gene does not seem to be affected by infection with $E$. coli in dioestrus, but in oestrus increases by $24 \mathrm{~h}$ pi (Figure 6).

Overall, most of the AMP genes we investigated were expressed at higher levels within the first 3-12 h pi. While the cycle stage seemed to have only a small overall effect on the response to E. coli, there seemed to be some variations in the response at the $12 \mathrm{~h}$ time point (Figure 6).

\section{Additional files}

Additional file 1. Mixed-effects logistic regression model for bacteria growth. Mixed-effects logistic regression model for bacteria growth in cultured biopsies obtained in oestrus and dioestrus before and at 3, 12, 24, 48 and $72 \mathrm{~h}$ after inoculation with $E$. coli.

Additional file 2. Statistical results for gene expression levels of all analysed genes. ANOVA, Bonferroni and interaction model results for the pathogen recognition receptors TLR2, TLR4, NLRC5, the chemokines CCL2, CXCL9, CXCL10, CXCL11, the tissue inhibitor of metallopeptidases (TIMP1) and the antimicrobial peptides lysozyme, lipocalin (LCN2), lactoferrin, uteroferrin, secretory leukoprotease inhibitor (SLPI), uterocalin P19, secreted phospholipase $A_{2}($ SPLA2) and equine $\beta$-defensin 1 (EBD1).

\section{Abbreviations}

CFU: colony forming units; E. coli: Escherichia coli (E. coli); LCN2: lipocalin 2; LFN: lactoferrin; LPS: lipopolysaccharide; MMP: matrix metalloproteinases; NLR: nucleotide-binding oligomerisation domain (NOD) receptor; P19: uterocalin P19; PAMP: pathogen-associated molecular pattern; PMIE: persistent matinginduced endometritis; S. equi ss zooepidemicus: Streptococcus equi subspecies zooepidemicus; SLPI: secretory leukoprotease inhibitor; 5 PLA : secreted phospholipase $\mathrm{A}_{2} ;$ TIMP: tissue inhibitor of metalloproteinases; TLR: Toll-like receptor; UFN: uteroferrin.

\section{Competing interests}

The authors declare that they have no competing interests.

\section{Authors' contributions}

CM participated in the animal experiment, carried out the analysis of the data and drafted the manuscript. SF participated in the analysis of the data. LG participated in the animal experiment. GB and NY participated in the design of the experiment. NK designed and participated in the animal experiment. All authors read and approved the final manuscript.

\section{Acknowledgements}

We would like to thank Professor Charles Bevins for his help with selecting genes of interest and Faye Docherty for her help with the production of histology slides.

\section{Funding}

This work was supported by funds from an Early Career Research Grant provided by the University of Melbourne. Neil Young holds an NHMRC Career Development Fellowship.

\section{Author details}

${ }^{1}$ Asia-Pacific Centre for Animal Health, Faculty of Veterinary and Agricultural Sciences, The University of Melbourne, Parkville, VIC, Australia. ${ }^{2}$ Translational Research and Animal Clinical Trial Study Group, Faculty of Veterinary and Agricultural Sciences, The University of Melbourne, Werribee, VIC, Australia.

${ }^{3}$ Faculty of Veterinary and Agricultural Sciences, The University of Melbourne, Parkville, VIC, Australia.

Received: 9 March 2016 Accepted: 26 July 2016

Published online: 08 November 2016

\section{References}

1. Zent WW, Troedsson MHT, Xue J-L (1998) Postbreeding uterine fluid accumulation in a normal population of Thoroughbred mares: a field study. In: Proceedings of the annual convention of the American Association of Equine Practitioners, Baltimore

2. Riddle WT, LeBlanc MM, Stromberg AJ (2007) Relationships between uterine culture, cytology and pregnancy rates in a Thoroughbred practice. Theriogenology 68:395-402 
3. Troedsson MHT, Loset K, Alghamdi AM, Dahms B, Crabo BG (2001) Interaction between equine semen and the endometrium: the inflammatory response to semen. Anim Reprod Sci 68:273-278

4. Watson ED (2000) Post-breeding endometritis in the mare. Anim Reprod Sci 60-61:221-232

5. Fumuso EA, Aguilar J, Giguere S, Rivulgo M, Wade J, Rogan D (2007) Immune parameters in mares resistant and susceptible to persistent post-breeding endometritis: effects of immunomodulation. Vet Immunol Immunopathol 118:30-39

6. Woodward EM, Christoffersen M, Campos J, Betancourt A, Horohov D (2013) Endometrial inflammatory markers of the early immune response in mares susceptible or resistant to persistent breeding-induced endometritis. Reproduction 145:289-296

7. Christoffersen M, Woodward E, Bojesen A, Jacobsen S, Petersen M, Troedsson M, Lehn-Jensen $\mathrm{H}$ (2012) Inflammatory responses to induced infectious endometritis in mares resistant or susceptible to persistent endometritis. BMC Vet Res 8:41

8. Bain AM (1966) The role of infection in infertility in the Thoroughbred mare. Vet Rec 78:168-173

9. Collins S (1964) A study of the incidence of cervical and uterine infection in Thoroughbred mares in Ireland. Vet Rec 66:673-676

10. Albihn A, Båverud V, Magnusson U (2003) Uterine microbiology and antimicrobial susceptibility in isolated bacteria from mares with fertility problems. Acta Vet Scand 44:121-129

11. Nikolakopoulos E, Watson ED (1999) Uterine contractility is necessary for the clearance of intrauterine fluid but not bacteria after bacterial infusion in the mare. Theriogenology 52:413-423

12. Troedsson M, Liu I, Thurmond M (1993) Function of uterine and bloodderived polymorphonuclear neutrophils in mares susceptible and resistant to chronic uterine infection: phagocytosis and chemotaxis. Biol Reprod 49:507-514

13. Troedsson MHT, Liu IKM, Ing M, Pascoe J, Thurmond M (1993) Multiple site electromyography recordings of uterine activity following an intrauterine bacterial challenge in mares susceptible and resistant to chronic uterine infection. J Reprod Fertil 99:307-313

14. LeBlanc MM, Neuwirth L, Asbury AC, Tran T, Mauragis D, Klapstein E (1994) Scintigraphic measurement of uterine clearance in normal mares and mares with recurrent endometritis. Equine Vet J 26:109-113

15. Evans MJ, Hamer JM, Gason LM, Graham CS, Asbury AC, Irvine CH (1986) Clearance of bacteria and non-antigenic markers following intra-uterine inoculation into maiden mares: effect of steroid hormone environment. Theriogenology 26:37-50

16. Marth CD, Young ND, Glenton LY, Noden DM, Browning GF, Krekeler N (2016) Effect of ovarian hormones on the healthy equine uterus: a global gene expression analysis. Reprod Fertil Dev 28(11):1810-1824

17. Christoffersen M, Baagoe C, Jacobsen S, Bojesen A, Petersen M, LehnJensen $H$ (2010) Evaluation of the systemic acute phase response and endometrial gene expression of serum amyloid $\mathrm{A}$ and pro- and antiinflammatory cytokines in mares with experimentally induced endometritis. Vet Immunol Immunopathol 138:95-105

18. Marth CD, Young ND, Glenton LY, Noden DM, Browning GF, Krekeler N (2015) Deep sequencing of the uterine immune response to bacteria during the equine oestrous cycle. BMC Genomics 16:934

19. Atli M, Kurar E, Kayis S, Aslan S, Semacan A, Celik S, Guzeloglu A (2010) Expression of Toll-like receptors (TLRs) in the equine endometrium during the estrous cycle. Reprod Domest Anim 45:58

20. Chow J, Young D, Golenbock D, Christ W, Gusovsky F (1999) Toll-like receptor-4 mediates lipopolysaccharide-induced signal transduction. J Biol Chem 274:10689-10692

21. Hoshino K, Takeuchi O, Kawai T, Sanjo H, Ogawa T, Takeda Y, Takeda K, Akira S (1999) Cutting edge: Toll-like receptor 4 (TLR4)-deficient mice are hyporesponsive to lipopolysaccharide: evidence for TLR4 as the Lps gene product. J Immunol 162:3749-3752

22. Matsuguchi T, Musikacharoen T, Ogawa T, Yoshikai Y (2000) Gene expressions of Toll-like receptor 2 , but not Toll-like receptor 4 , is induced by LPS and inflammatory cytokines in mouse macrophages. J Immunol 165:5767-5772

23. Barbé F, Douglas T, Saleh M (2014) Advances in NOD-like receptors (NLR) biology. Cytokine Growth Factor Rev 25:681-697

24. Zlotnik A, Yoshie O (2012) The chemokine superfamily revisited. Immunity 36:705-716
25. Cole AM, Ganz T, Liese AM, Burdick MD, Liu L, Strieter RM (2001) Cutting edge: IFN-inducible ELR - CXC chemokines display defensin-like antimicrobial activity. J Immunol 167:623-627

26. Yang D, Chen Q, Hoover DM, Staley P, Tucker KD, Lubkowski J, Oppenheim JJ (2003) Many chemokines including CCL20/MIP-3a display antimicrobial activity. J Leukoc Biol 74:448-455

27. Bruhn O, Grötzinger J, Cascorbi I, Jung S (2011) Antimicrobial peptides and proteins of the horse-insights into a well-armed organism. Vet Res Commun 42:98

28. Linde A, Ross C, Davis E, Dib L, Blecha F, Melgarejo T (2008) Innate immunity and host defense peptides in veterinary medicine. J Vet Intern Med 22:247-265

29. Nevalainen TJ, Graham GG, Scott KF (2008) Antibacterial actions of secreted phospholipases A2. Biochim Biophys Acta 1781:1-9

30. Tomee JF, Koeter GH, Hiemstra PS, Kauffman HF (1998) Secretory leukoprotease inhibitor: a native antimicrobial protein presenting a new therapeutic option? Thorax 53:114-116

31. Couto M, Harwig S, Cullor J, Hughes J, Lehrer R (1992) eNAP-2, a novel cysteine-rich bactericidal peptide from equine leukocytes. Infect Immun 60:5042-5047

32. Couto M, Harwig S, Lehrer R (1993) Selective inhibition of microbial serine proteases by eNAP-2, an antimicrobial peptide from equine neutrophils. Infect Immun 61:2991-2994

33. Flo T, Smith K, Sato S, Rodriguez D, Holmes M, Strong R, Akira S, Aderem A (2004) Lipocalin 2 mediates an innate immune response to bacterial infection by sequestrating iron. Nature 432:917-921

34. Farnaud S, Evans R (2003) Lactoferrin — a multifunctional protein with antimicrobial properties. Mol Immunol 40:395-405

35. Appelmelk B, An Y-Q, Geerts M, Thiijs B, De Boer H, MacLaren D, De Graaff J, Nuijens J (1994) Lactoferrin is a lipid A-binding protein. Infect Immun 62:2628-2632

36. Roberts RM, Raub TJ, Bazer FW (1986) Role of uteroferrin in transplacental iron transport in the pig. Fed Proc 45:2513-2518

37. Wooding FBP, Morgan G, Fowden AL, Allen WR (2000) Separate sites and mechanisms for placental transport of calcium, iron and glucose in the equine placenta. Placenta 21:635-645

38. Stewart F, Kennedy MW, Suire S (2000) A novel uterine lipocalin supporting pregnancy in equids. Cell Mol Life Sci 57:1373-1378

39. Van den Steen PE, Proost P, Wuyts A, Van Damme J, Opdenakker G (2000) Neutrophil gelatinase B potentiates interleukin-8 tenfold by aminoterminal processing, whereas it degrades CTAP-III, PF-4, and GRO-alpha and leaves RANTES and MCP-2 intact. Blood 96:2673-2681

40. McQuibban GA, Gong J-H, Wong JP, Wallace JL, Clark-Lewis I, Overall CM (2002) Matrix metalloproteinase processing of monocyte chemoattractant proteins generates CC chemokine receptor antagonists with anti-inflammatory properties in vivo. Blood 100:1160-1167

41. Mercer P, Shute J, Bhowmik A, Donaldson G, Wedzicha J, Warner J (2005) MMP-9, TIMP-1 and inflammatory cells in sputum from COPD patients during exacerbation. Respir Res 6:151

42. Kotilainen T, Huhtinen M, Katila T (1994) Sperm-induced leukocytosis in the equine uterus. Theriogenology 41:629-636

43. Kenney R, Doig P (1986) Equine endometrial biopsy. In: Marrow D (ed) Current therapy in theriogenology: diagnosis, treatment, and prevention of reproductive diseases in small and large animals. W.B.Saunders, Philadelphia, pp 723-729

44. Christoffersen M, Woodward EM, Bojesen AM, Petersen MR, Squires EL, Lehn-Jensen H, Troedsson MHT (2012) Effect of immunomodulatory therapy on the endometrial inflammatory response to induced infectious endometritis in susceptible mares. Theriogenology 78:991-1004

45. Davis E, Sang Y, Blecha F (2004) Equine $\beta$-defensin-1: full-length cDNA sequence and tissue expression. Vet Immunol Immunopathol 99:127-132

46. Ye J, Coulouris G, Zaretskaya I, Cutcutache I, Rozen S, Madden T (2012) Primer-BLAST: a tool to design target-specific primers for polymerase chain reaction. BMC Bioinform 13:1-11

47. Traub-Dargatz JL, Salman MD, Voss JL (1991) Medical problems of adult horses, as ranked by equine practitioners. J Am Vet Med Assoc 198:1745-1747

48. Maloufi F, Pierson R, Otto S, Ball C, Card CR (2002) Mares susceptible or resistant to endometritis have similar endometrial echographic and inflammatory cell reactions at 96 hours after infusion with frozen semen and extender. Proc Am Assoc Equine Pract 48:51-57 
49. Cui J, Zhu L, Xia X, Wang HY, Legras $X$, Hong J, Ji J, Shen P, Zheng S, Chen ZJ, Wang R-F (2010) NLRC5 negatively regulates the NF-KB and type I interferon signaling pathways. Cell 141:483-496

50. Davis BK, Roberts RA, Huang MT, Willingham SB, Conti BJ, Brickey WJ, Barker BR, Kwan M, Taxman DJ, Accavitti-Loper M-A, Duncan JA, Ting JP-Y (2011) Cutting edge: NLRC5-dependent activation of the inflammasome. J Immunol 186:1333-1337

51. Conti P, Boucher W, Letourneau R, Feliciani C, Reale M, Barbacane R, Vlagopoulos P, Bruneau G, Thibault J, Theoharides T (1995) Monocyte chemotactic protein-1 provokes mast cell aggregation and [3H] 5HT release. Immunology 86:434-440

52. Taub DD, Lloyd AR, Conlon K, Wang JM, Ortaldo JR, Harada A, Matsushima K, Kelvin DJ, Oppenheim JJ (1993) Recombinant human interferoninducible protein 10 is a chemoattractant for human monocytes and T lymphocytes and promotes T cell adhesion to endothelial cells. J Exp Med 177:1809-1814

53. Cole KE, Strick CA, Paradis TJ, Ogborne KT, Loetscher M, Gladue RP, Lin W, Boyd JG, Moser B, Wood DE, Sahagan BG, Neote K (1998) Interferoninducible T cell alpha chemoattractant (I-TAC): a novel non-ELR CXC chemokine with potent activity on activated $T$ cells through selective high affinity binding to CXCR3. J Exp Med 187:2009-2021

54. Liao F, Rabin RL, Yannelli JR, Koniaris LG, Vanguri P, Farber JM (1995) Human Mig chemokine: biochemical and functional characterization. J Exp Med 182:1301-1314

55. Yung SC, Murphy PM (2012) Antimicrobial chemokines. Front Immunol $3: 276$
56. Ulug U, Goldman S, Ben-Shlomo I, Shalev E (2001) Matrix metalloproteinase (MMP)-2 and MMP-9 and their inhibitor, TIMP-1, in human term decidua and fetal membranes: the effect of prostaglandin F2 $a$ and indomethacin. Mol Hum Reprod 7:1187-1193

57. Christiaens I, Zaragoza DB, Guilbert L, Robertson SA, Mitchell BF, Olson DM (2008) Inflammatory processes in preterm and term parturition. J Reprod Immunol 79:50-57

58. Walter I, Handler J, Miller I, Aurich C (2005) Matrix metalloproteinase 2 (MMP-2) and tissue transglutaminase (TG 2) are expressed in periglandular fibrosis in horse mares with endometrosis. Histol Histopathol 20:1105-1113

59. Lehrer RI, Barton A, Daher KA, Harwig S, Ganz T, Selsted ME (1989) Interaction of human defensins with Escherichia coli. Mechanism of bactericidal activity. J Clin Invest 84:553

60. Pellegrini A, Waiblinger S, von Fellenberg R (1991) Purification of equine neutrophil lysozyme and its antibacterial activity against Gram-positive and Gram-negative bacteria. Vet Res Commun 15:427-435

61. Weinrauch Y, Elsbach P, Madsen LM, Foreman A, Weiss J (1996) The potent anti-Staphylococcus aureus activity of a sterile rabbit inflammatory fluid is due to a 14-kD phospholipase A2. J Clin Invest 97:250

62. Hayes M, Quinn B, Lillie B, Côté O, Bienzle D, Waelchli R, Betteridge K (2012) Changes in various endometrial proteins during cloprostenolinduced failure of early pregnancy in mares. Anim Reprod Sci 9:723-741

63. Li C, Chan YR (2011) Lipocalin 2 regulation and its complex role in inflammation and cancer. Cytokine 56:435-441

\section{Submit your next manuscript to BioMed Central and we will help you at every step:}

- We accept pre-submission inquiries

- Our selector tool helps you to find the most relevant journal

- We provide round the clock customer support

- Convenient online submission

- Thorough peer review

- Inclusion in PubMed and all major indexing services

- Maximum visibility for your research

Submit your manuscript at www.biomedcentral.com/submit 